Article

\title{
From Tactical Urbanism Action to Institutionalised Urban Planning and Educational Tool: The Evolution of Park(ing) Day
}

\author{
Krzysztof Herman ${ }^{1, *(1)}$ and Maria Rodgers ${ }^{2}$ (1) \\ 1 Department of Landscape Art, Institute of Environmental Engineering, Warsaw University of Life Sciences \\ (WULS-SGGW), 02-787 Warsaw, Poland \\ 2 Te Kura Waihanga-Wellington School of Architecture, Te Herenga Waka-Victoria University of Wellington, \\ 139 Vivian Street, Te Aro, Wellington 6011, New Zealand; maria.rodgers@vuw.ac.nz \\ * Correspondence: krzysztof_herman@sggw.edu.pl
}

Received: 20 May 2020; Accepted: 1 July 2020; Published: 3 July 2020

check for updates

\begin{abstract}
A singular and modest activist action, a temporary park created in San Francisco, grew into the global urban Park(ing) Day (PD) phenomenon. This tactical urbanism event not only expanded to be annually celebrated in thousands of parking lots all over the world but became an inspiration for urban planning and policy changes. The permanent rendition of Park(ing) Day, parklets, resulted from the movement but did not stop the spread of PD itself. This article presents case studies from New Zealand and Poland, two geographically and culturally distant locations where PD has further developed and evolved gaining local qualities. Through research methods such as research in design, secondary data analysis and expert interviews we study the trajectory of PD evolution and the role and interpretation of it in different parts of the globe. The results show a narrative of successive popularisation and institutionalisation as well as diversification. Departing from its grassroots, guerilla and assertive traits, PD has grown to become an artistic, creative and urban planning tool. As an established, recognised action and an 'attractive' idea, PD has great potential for designer education, allowing a venue for implementing methods such as design-build and live project.
\end{abstract}

Keywords: tactical urbanism; temporary installation; urban prototyping; park(ing) day; grassroots urbanism; parklets; design-build; landscape architecture teaching; urban planning; park(ing) day

\section{Introduction}

\subsection{Context of Car-Free Movements}

The issues of car-free cities (or car-free zones within cities) and the safety of streets as public spaces, were becoming recognised in the 1960s: in the UK 'the Buchanan Report' [1], in Sweden SCAFT guidelines (Principles for urban planning with respect to road safety) [2] and perhaps most famously in the USA with the publication of the 'Life and Death of Great American Cities' [3]. The first Woonerf, an environment unfriendly to cars but suitable for children and other pedestrians, was created as an illegal project led by local residents in 1968 in Groningen, the Netherlands [4]. Woonerfs or 'Living streets' have become popular in the Netherlands and other parts in Europe as public areas serving primarily as places for walking and playing, with only local traffic [5].

The history of car-free days can be traced as far back as the middle of the XX century. During the Suez crisis in 1956 and in subsequent years oil was rationed in the Netherlands and during this emergency November 4th became the first Car-Free Sunday [6]. Several other countries including Denmark, Germany and Switzerland adopted the idea of a (top-down, centralised) car-free day in the seventies as a way of battling fuel shortages in crisis times (e.g., in 1973 during the Yom Kippur War [7]). 
Carless days were introduced in New Zealand in July 1979 but did little to reduce fuel consumption and were abolished in May 1980 [8]. In a presentation delivered at the International to the Ciudades Accesibles Congress in 1994, Eric Britton of EcoPlan noted: "There is nothing, of course, that is new about a proposal for a car-free day. In addition to a large number of small city center closure projects and pedestrian zones of varying sizes and sorts, over the last two decades there have been hundreds of cases of cities that have banned car traffic for a single day, some special event, or during some particular (usually crisis) period" [9].

His proposal at the Congress was to promote Car-Free Days (CFDs) as a non-crisis, voluntary event "to probe in a structured way for eventual alterations in future policy packages" [9]. It was the outline of a global urban prototyping project which led to several CFDs in subsequent years (Reykiavik, Iceland and Bath, UK in 1996; La Rochelle, France and Weybridge, UK in 1997 were some of the first participants). CFD became popular in the Western Europe at the turn of the century, adding an essential programme element to European Mobility Week (EMW) which was established in 2002 by the European Commission. In 2019, EMW had 44 countries and 1820 cities participating.

Another successful and global grassroots nonviolent direct action, Critical Mass, described as a 'traffic jam on bikes' started in 1992 in downtown San Francisco [10]. Critical Mass highlights the imbalance that exists between bicycles and cars when it comes to safety and access, and on this day, bikes take priority and reclaim the street back from motor traffic. It has also gained significant recognition globally with over one hundred cities involved after only eight years of running [11].

Car-free zones have been very apparent in the historic centres of European cities and have recently made their way into the planning of sustainable suburbs $[12,13]$. Today scientists and policymakers argue that cites should look towards being partially or entirely car-free [14]. Hamburg, Oslo, Helsinki, and Madrid have announced their plans to become partly private car-free. Other cities like Paris, Milan, Chengdu, Masdar, Dublin, Brussels, Copenhagen, Bogota, and Hyderabad have made efforts to reduce motorized traffic with car-free days, investing in cycling infrastructure and pedestrianization, as well as restricting parking spaces and increasing public transport provision [15].

\subsection{Park(ing) Day Origins as Tactical Urbanism Action}

One parking spot in central San Francisco was, for two hours on a November day in 2005, transformed into a public space. Parking was paid for at the parking meter but instead of depositing a rectangular steel box on four wheels, activists-designers from the Rebar group used these 12 square meters to park a park. They laid out some lawn, a bench and a tree [16] (Figure 1).

The allure of temporary urban projects is the magnetism of the experimental and the pioneering, plus the exploration and physical occupation of underused, neglected and marginal sites [17]. Underused places within the urban fabric are not necessarily peripheral, they can escape our sight and imagination due to stagnation, habits, social norms and 'usual patterns' of behaviour.

Such a pattern can be recognised within the allocation of space and use on urban streets as well as the proportions in the area assigned for pedestrians, cars, bicycles and other transportation modes.

Activists from Rebar group tackled one parking spot at a time, but "the combination of the iconic image of parking-space-as-park and its accompanying descriptive name created a 'sticky' idea that transmitted readily across electronic media" [18]. In 2006 this ephemeral installation grew into a movement named "Park(ing) Day" (PD) which was aimed specifically at drawing attention to the lack of green space in the downtown area of San Francisco [19], and with a wider scope, debating the appropriation of urban space. The event quickly became an officially supported endeavor; San Francisco Mayor Gavin Newsom allowed activists to take over his private parking space [19]. The number of PD spots grew rapidly into a global event on six continents and thirty-five countries [20] (Figure 2). PD is one day a year, but the images, videos, website, articles and other forms of documentation enable constant dissemination and the 'virality' of the idea [21]. 


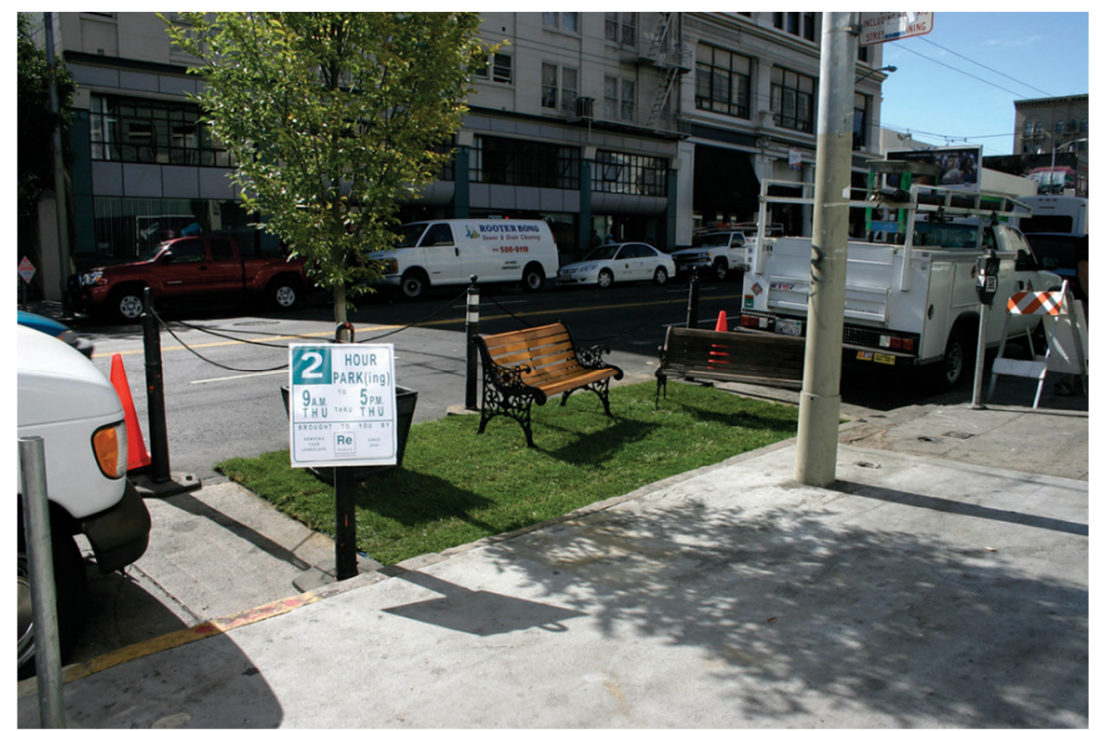

Figure 1. One of several Park(ing) Day parks that were set up in San Francisco by Rebar Group during the first official edition of the event (2006). Photo by Rebar (Creative Commons by licence).

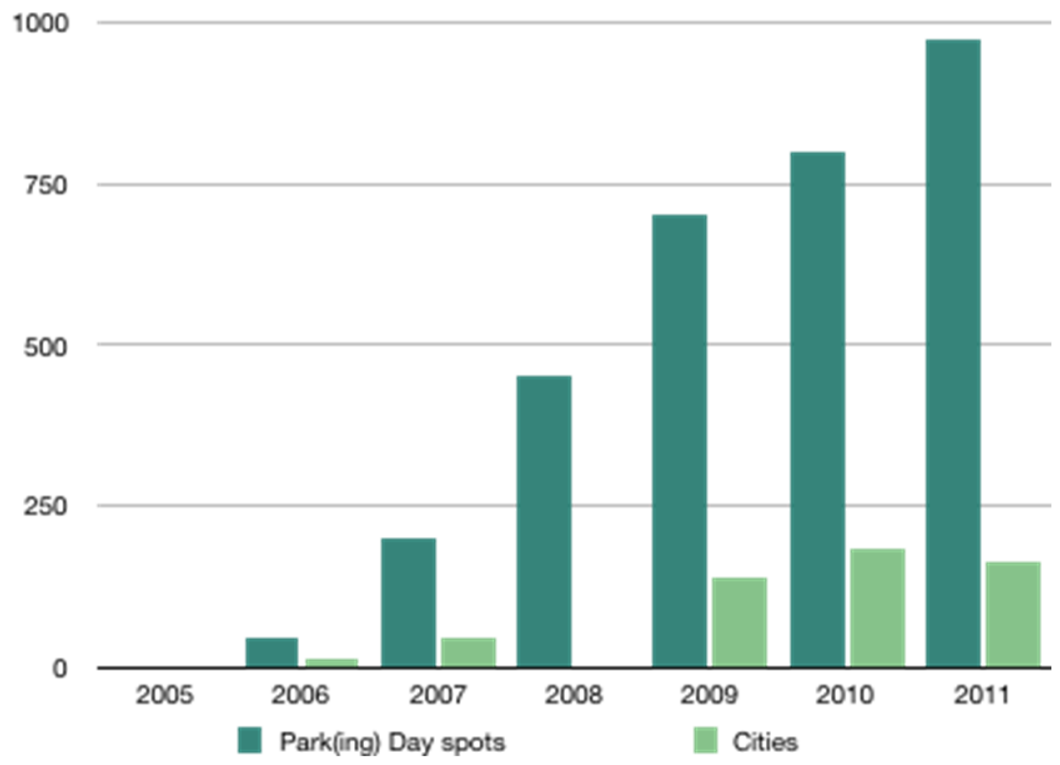

Figure 2. Growth of Park(ing) Days (PD) from 1 spot in 1 city (2005) to 975 parks created in 162 cities in 35 counties in 2011 (last year of formal counts) [20]. No data for the number of cities participating in 2008. Based on data from press releases and Coombs G. [19].

A small-scale, temporary event, an ad-hoc action in public space can spark a change leading to permanent solutions. This can happen accidentally, spontaneously or organically as an 'everyday urbanism' situation [22], but can also be a part of a strategy. The strategy has many names: tactical urbanism [23], urban acupuncture [24], guerilla urbanism [25], 'do it yourself' (DIY) urbanism [26] or creative user generated urbanism [27].

Park(ing) Day, an attractive idea with great potential for capturing imagination on a global scale has been appropriated by all of these strategies and used as a case study that supports them. Park(ing) Day is an example of urban acupuncture: a practice that targets local points of significance, while attempting to heal or "energize" the larger urban space or the whole city [28]. It definitely was a 'do it yourself' (DIY) project instigated, designed, created, paid for and implemented by single users or small voluntary groups [26]. It is a form of insurgent urbanism and guerilla action, in opposition to the conventional practice of urban planning, and in defiance of official rules and regulations [25]. 
In the Park(ing) Day Manifesto [29], published in 2011 by the leaders of PD movement, Rebar Group, the activists uniquely describe their actions as generous, authentic and absurd urbanism. The generosity creates an interaction between strangers that produces new cultural value, without commercial transaction. It offers something (experience, exchange, experiment etc.) without expectation of anything in return, which can be perceived by passers-by as subversive and suspicious, but could potentially be profound and transformative [29]. PD was also designed to instigate unscripted interaction and playful experimentation. The playfulness makes it seem absurd-a public park in a metered parking space is a surrealistic interruption in the fabric of everyday urban life. It is a prototype, a temporary alternate vision of urban space with a very strong and clear message that, despite rapid growth and diversification, remains consistent due to the act of reimagining and reconstructing physical parking spaces [21].

International Park(ing) Day is held each year on the third Friday of September each year, uncoincidentally often overlapping with 22 September the set date for World Car-Free Day and European Mobility Week (EMW).

\subsection{From Park(ing) Day to Institutionalised 'Pavement to Parks' Policy}

Rebar's Park(ing) Day Manual (2011) claimed "that 'permanent change' can be a result of Park(ing) Day efforts" [21]. Change did take place as Park(ing) Day raised awareness about the need for and use of public space in San Francisco and prompted the San Francisco Planning Department (SFPD) to develop the 'Pavement to Parks' program [19]. The SFPD's pilot project in 2009 was Castro Commons which was defined as removable so as to expedite the design review process and construction [30]. San Francisco coined the term parklets [30] and in 2010 parklets were installed as part of the Pavement to Parks program. This was a collaborative effort between the San Francisco Planning Department, the Department of Public Works, the Municipal Transportation Agency, and the Mayor's Office [31].

In her review of a trial parklet in 2010, Pratt stated that "Parklets repurpose two to three parking stalls along a block into a public space for people to enjoy the city" [32]. The SFPD created the 'Pavement to Parks Manual', an easy-to-use guide for designing approved parklets in the city and streamlined the permitting for these spaces, the processing of applications and selection of sites, and their installation by private parties such as businesses and residents [30]. It asserted that parklets are public and for any passersby, not just those patronizing nearby businesses [23].

\subsection{Development of 'Pavement to Parks' as Permanent Park(ing) Day}

The progression from Park(ing) Day installation to parklet was a move from a very ephemeral, day long 'urban acupuncture' to semi-permanent business or institution operated mini street 'parks'. Parklets became a popular form of new public space in the times of increasing awareness of the need for more public space, increased interest in placemaking and the new movement towards reclaiming the streets. Involving business owners as well as community organizations and residents in the creation of public space was an economic solution to these concerns plus a way to encourage pedestrians, foster communities and support local businesses [16].

Like the first Park(ing) Day installation in 2005 parklets are proposed and installed in areas lacking public space and the parklet come to be seen as an institutionalized Park(ing) Day. Both Park(ing) Day and 'Pavement to Parks' seek to address the challenging questions facing cities, including financial difficulties, rapid urbanization and densification which all cause pressure on existing public space; "parklets fit these needs as inexpensive, semi-permanent projects based on a public-private partnership model" [33]. The major difference between Park(ing) Day and 'Pavement to Parks' is in duration. Parklets last longer than a Park(ing) Day installation but are still considered temporary with permits for a few months to a year with options for time extensions [31]. This gives the 'Pavement to Parks' program and the sponsor the ability to regularly reassess the ongoing success of each parklet and increases the benefits of the new public space. These benefits include the following: increased social benefits due to increased neighbourhood interactions and liveability; increased pedestrian activity and 
the flow on effects of increased economic activity; increased cycling due to the inclusion of bike racks; and traffic calming [31].

The costs of parklets are of course greater than those of Park(ing) Day installations due to their intended duration and the guidelines that need to be met, for example, the parklet needs to be built on a platform to enable a smooth transition from sidewalk to parklet. They "provide space for socializing that is safe from vehicles" [16].

Parklets are predominantly sponsored by the business they flank which seeks to increase revenue due to increased pedestrians. These businesses are mainly cafes and restaurants which cannot provide table service to the parklet asserting that the parklet is a public space [30]. Some parklets are funded and maintained by residents and community organisations [31].

Parklets provide "opportunities to innovate in the form and function of public space and build collaboration between local government, businesses, customers, designers and residents" [34] in the shaping of the public realm. While not having significant impact on vehicular travel they do affect pedestrian travel, with parklets having seating and tables seeing a greater increase in foot traffic or stationary activities than those without [35].

Like Park(ing) Day the diversity of parklets is celebrated and they are encouraged "to have unique character and display a sense of belonging to their particular neighbourhood" [30]. There is a greater variety of the size of parklets than Park(ing) Day installations, for example, one parklet runs along two blocks and along both sides of the street [30]. Parklets range in type and quality, from temporary grass-covered miniparks to moveable semi-permanent wooden decks with bike parking, public art, benches, tables, chairs, and even exercise equipment [23].

'Pavement to Parks' and 'Living Innovation Zones' (LIZ) projects are both now known as 'Groundplay' projects. The aim of this change was to unite marketing efforts, highlight commonalities and create a unified brand with a name that captured the mission and spirit of the program [36]. This rebranding came into effect with the launching of the 'Groundplay' website (groundplaysf.org) in March 2017. 'Groundplay' emphasizes a grassroots process that is cost-efficient, quick, community-driven and that can sustain real and integrated change in contrast to top-down government planning. Funding varies from project to project and may come from local business, a civic group or a government entity [36]. There were no parklets installed between 2016-2018, and only one in 2019. During the period of 2016-2018 the SFPD focused on updating their materials and preparing a rolling application process, so that applications are now accepted year round. The San Francisco Parklet Manual was re-issued in 2019 pointing to fresh interest and support for the program. The aim was to make the graphics user-friendly to make the program more accessible to project sponsors without a design background. The SFPD are working to develop more engagement tools, which may include a "kit of parts", so as to lower participation barriers and costs.

Over the past nine years, of the 76 parklets installed in San Francisco 59 remain and 17 have been removed; the parklets have taken over 109 parking spaces "adding 19,620 square feet of open space to the city" [36]. The parklet program did not bring to an end the Park(ing) Day movement in San Francisco. In both 2018 and 2019 Park(ing) Day was part of the Architecture and the City Festival and there were 9 installations each year. The SFPD is not involved with the organization of Park(ing) Day. Globally the parklet movement has grown and in 2016 more than 80 cities around the world had installed parklets or had similar programs; these were mostly in the U.S.A., but also in South America, Europe, Australia and New Zealand, with many other cities currently working to develop such programs [16].

The popularity and global reach of PD and the development of parklets presents an unprecedented evolution of a tactical urbanism action. This article aims to answer the following research question: with Parklets assuming the role of permanent, institutionalised versions of temporary PD installations, what is the value of PD today? This will be achieved by looking at two case studies, the evolution of PD in two different countries (22 cities). Additionally, we ask the questions: What is the trajectory of PD evolution and what is the role of institutions in this? Did institutions nullify or neutralise PD's core 
tactical/critical values? How did PD transform with globalisation and what is the reception of it in different parts of the globe? The subject of the current role of PD will also be discussed, with regards to the potential significance of such tactical urbanism actions in design education and as a temporary response to unexpected circumstances, such as the current COVID-19 pandemic.

\section{Materials and Methods}

Park(ing) Day as a global movement grew quickly outside the borders of San Francisco and the USA. It reached Poland and New Zealand, geographically and culturally distant places, in the same year (2009). This research focused on the reception of the event in both countries so as to understand the universal lure of PD as a cross-border phenomenon. The developments of PD initiatives across several cities in Poland and New Zealand are treated here as case studies. Case study analysis is a prominent and well-established research method in landscape architecture [37] and urban planning [38]. Case studies typically employ a variety of research methods (Table 1) including experimental, quasi-experimental, historical, storytelling and anecdotal documentation [37]. In the multimethod approach case study, we have employed the following:

1. Desk research and secondary data analysis [39]. The analysis of data from press coverage and official press releases, as well as data provided by institutions, groups and activists responsible for the organisation of PD in respective cities, was undertaken. This included photographic archives provided by Wellington Sculpture Trust, the organising body for Wellington PD.

2. Semi-structured expert interviews. The otherwise open format of interviews included several fixed components, including questions on: the overall number of PD editions in a certain city; the initiation of the event; the organisational structure; organisational and financial support from institutions (namely the city councils); the particular expert's involvement; additional topics and themes (other than the original PD theme of quality of public space and dominance of cars). The intention was to interview at least one expert from each city in Poland and New Zealand in which PD was organised. The interview process planned for March-April 2020 was shaped by the consequences of national lockdowns in Poland and New Zealand. Most interviews were carried out via distance and included exchange of emails, instant messaging and phone calls.

3. Research by design [40-42] and participant observation [38,43,44]. Authors of the article have been involved in organisation and design (K. Herman PD, Warsaw, Poland, 2009-2011) or design (K. Herman, M. Rodgers PD, Wellington 2020) of PD events and installations. Research through art and design is material-based research, development work and active research through practical experiments [42]. Participants in the design process are placed in the position to creatively exchange, collaborate and develop new knowledge together [45]. Both K. Herman and M. Rodgers have also analysed several other PD events as observers and casual participants employing the participant observation method, which allows the researcher to obtain first-hand knowledge and to 'get close to the data', thereby developing the analytical, conceptual, and categorical components of explanation from the data itself [38].

Table 1. Methods and data sources.

\begin{tabular}{ccc}
\hline Method & Data/Information Source & Number of Instances/Objects \\
\hline Desk research/secondary data analysis & Press coverage, archives, websites & $\begin{array}{c}\text { 25 events in 7 cities in New Zealand } \\
49 \text { events in 15 cities in Poland }\end{array}$ \\
\hline Semi-structured expert interviews & $\begin{array}{c}\text { Face to face meetings, phone calls and online } \\
\text { exchanges (email, instant messaging) }\end{array}$ & $\begin{array}{c}\text { 14 experts from 6 cities in New Zealand } \\
\text { 17 experts from 15 cities in Poland }\end{array}$ \\
\hline Research by Design & Participation in the design and building process & $\begin{array}{c}\text { 1 PD installation in Wellington, NZ(2020) } \\
\text { 4 PD installations in Warsaw, PL } \\
\text { (2009-2011) }\end{array}$ \\
\hline Participant observation & Observation, incidental conversation, & 2 PD events in New Zealand (2019-2020) \\
& engagement PD events in Poland (2009-2012) & 5
\end{tabular}




\section{Results}

\subsection{Case Study: Park(ing) Day in Poland}

After the first Park(ing) Day in 2005, it blossomed into a worldwide grassroots movement. In 2008 there were more than 500 Park(ing) Day installations in more than 100 cities on four continents. In 2009, there were first-time installations in Poland and New Zealand as well as South Africa, Norway, and South Korea [46].

The first Park(ing) Day installations in Poland in 2009 were built in Warsaw and Kraków. In both cities they were initiated by informal groups but supported by institutions. Although organisers had procured official permission for the occupation of parking spaces, in these early events the parking meter still had to be fed. Krzysztof Herman led the organisation of the PD event in Warsaw and received financial support from the Environmental Protection Office of Warsaw City Council. It was a last minute addition to the program and budget of Car-Free Day and European Mobility Week. Two temporary 'parks' were created on 3 parking spaces; one took over two spaces (Figure 3). The occupation lasted for 3 days, although the installations had to be disassembled in the evening and reassembled each morning. The mini-parks had a rather typical form and were visibly inspired by the first PD installation in San Francisco. They included elements such as rolled-out lawn, potted plants, a bench, a blow-up pool, etc. Unfortunately, cars and trucks were involved in transportation of the materials and for overnight occupation of the parking spaces. This led to a desire for the next year's event to be entirely car-free. In 2010, a cargo-bike and a rickshaw were used to transport plants, chairs and tables. The themes of this event also evolved and became more diverse. 'Bring your own plant' enabled community participation in the collective building of the park. Participants could leave their house plants in the installation for the day on their way to work and collect them later in the evening. In 2011, the event focused on the mobility of the temporary park and was a 'park on wheels', that was foldable and designed to be moved from one parking spot to another with the use of public transport.

These installations were all organised by informal groups that included many volunteer landscape architecture students. In 2012, former students took over the organisation and scaled up the temporary garden with more greenery, bales of hay and an ambitious program of concerts, games and workshops.

The Warsaw PD events in 2010, 2011 and 2012 were not recognised or sponsored by the city or any other institution. The organisers used the permission documents from 2009 as support when talking to officers of the Municipal Police.

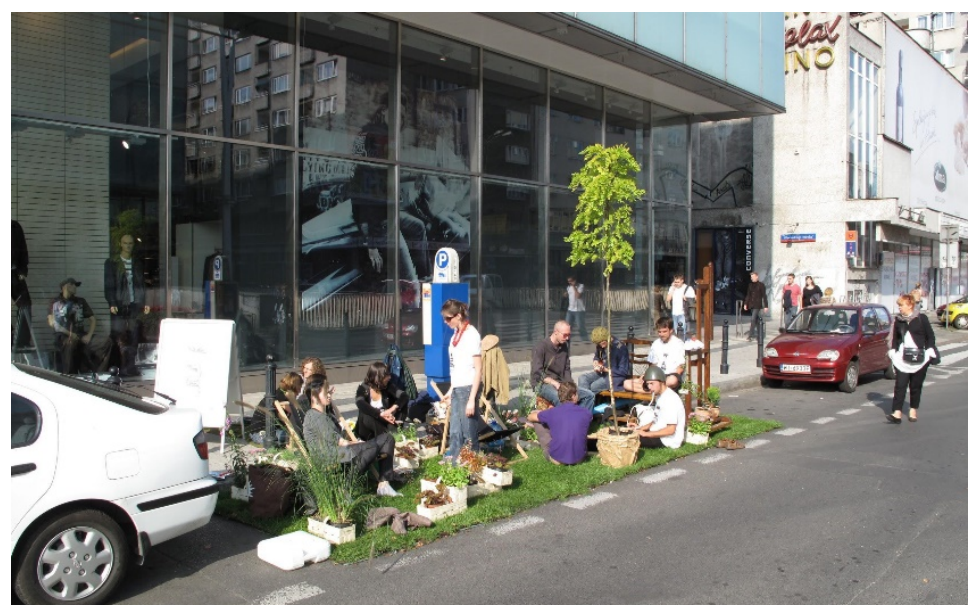

Figure 3. First Park(ing) Day in Warsaw (2009) organised by K. Herman. (photo K. Herman).

The history of Cracow PD seems to be much more political. The cycling activists from Critical Mass saw PD as a chance to spark real change in the urban policies of their city. Each year they would 
gather signatures for a petition on the extension of the paid parking zone or on establishing a living street/shared zone. These actions had almost immediate effect and resulted in permanent closures of the suggested streets to car traffic within a year. One of the organisers of PD in Cracow subsequently became the Cycling Officer and continued organising the event in 2014-2016.

PD in Poznan from its very beginning in 2013 was a well organised, institutionalised event and a part of the city's largest cultural festival 'Malta', which is subsidised by the city council. In the first two years the focus was on single parking spaces, the design of which was selected in an architectural competition under the auspices of the Society of Polish Architects and aimed mostly at students and young professionals. Since 2016, Poznań's PD has grown in scale and included 30-40 park(ing) spaces. Local businesses were invited to join creating temporary pavement cafes, outdoor libraries or art workshop spaces. As in Cracow, this created some long-term changes, such as restaurants and bars being able to continue the occupation of some of the parking spaces during the summer season.

PD during the 2014 local elections became a tool for political campaigns. Activists and local political non-mainstream groups used PD as a publicity stunt to get media attention for their programmes and ideas. '\#Zielona Oaza' ('\#Green Oasis') in Warsaw, Gorzów, Chojnice and other cities aimed to instigate debate on the quality of urban space while promoting the coalition Urban Social Movements in the elections. However, in Gorzów and Chojnice this was cut short by the reaction of the Municipal Police. The city of Gorzów recognised its faux pas and allowed for an officially permitted event the following year.

Landscape architects and architects were very active in the creation of PD installations in Warsaw, and also in Wrocław, where in 2013 one of local small LA offices organised perhaps the largest independent PD event in Poland, without any support from the city council, which saw 25 parking spaces occupied.

PD in Łódź (the third largest city in Poland) represents a rather typical story of the event's evolution, beginning in 2010 with an independently organised, guerilla and low-budget parking lot occupation by activists from Critical Mass. Then in 2013, PD was a sponsored event organised by a local community group. The final step in the evolution came in 2014-2017 when PD became an official city council event, held in a parking lot outside the council offices. Łódź was also the first city in Poland to build a permanent parklet in 2017.

Several smaller cities such as Tczew $(2018,2019)$, Kalisz (2017) and Zielona Góra (2015) joined the global movement later with the events organised or fully sponsored by the municipality, or, for example, cycling officers.

PD events in almost every city in Poland are connected to Car-Free Day and European Mobility Week. Table 2 presents the growth and spread of PD in Poland. From 2013 onwards, in many cases, such as in Lublin, Łódź, Szczecin and Olsztyn, PD became a sort of 'family picnic' coordinated by city councils with a focus on promoting cycling and public transportation. In Lublin, in 2013, the name of the event on official posters was actually 'Parking Picnic'.

\subsection{Case Study: Park(ing) Day in New Zealand}

The first Park(ing) Day in New Zealand, on 18 September 2009, was a collaboration between a variety of people and organizations, including Intersect, Heart of the City, the Sustainability Trust, Frocks on Bikes, Cycle Aware Wellington, 350 Aotearoa and local businesses. Passers-by were encouraged to contribute change to pay the parking meters [46]. In Wellington, however, the council threatened to remove Intersect Network's temporary installations until permits were quickly negotiated. A few days later in Christchurch, on 22 September, World Car-Free Day, 'Living Streets Aotearoa' (who seek people-friendly and climate-friendly cities) created mini-parks in metered car park spaces and paid the meter. Although not called Park(ing) Day there was reference to PD in Wellington the previous week. Table 3 presents the growth and spread of PD in New Zealand. 
Table 2. City council involvement (black—city council financial support; dark grey-cc agreement/ permission; light grey-independent-no support) and the amount of parking spaces taken over during PD (numbers). Additional key: —estimated number; $x$ - event on a street closed for traffic; \#—event at a closed up private parking lot; ^ - event at a closed up public parking lot; c-Cargo Park(ing) Day—presentation of cargo bikes without parking spots taken over; i-event inspired by Park(ing) Day but not on a parking spot.

\begin{tabular}{|c|c|c|c|c|c|c|c|c|c|c|c|}
\hline & 2009 & 2010 & 2011 & 2012 & 2013 & 2014 & 2015 & 2016 & 2017 & 2018 & 2019 \\
\hline Warszawa & 3 & 1 & 3 & 4 & & $\mathrm{i}$ & & & 1 & & \\
\hline Kraków & 2 & 4 & 4 & & 1 & 4 & 4 & C & & & \\
\hline Poznań & & & & & 1 & 3 & 1 & $\sim 30$ & $\sim 30$ & $\sim 40$ & $\sim 10 \mathrm{x}$ \\
\hline Wrocław & & & $x$ & & 25 & & & & & & \\
\hline Łódź & & 15 & & & 30 & $\sim 25^{\prime}$ & $\sim 25$ & r & & & \\
\hline Lublin & & & 10 & & 10 & 10 & 10 & & & & \\
\hline Olsztyn & & & 10 & 18 & & 3 & & 1 & & & \\
\hline Gorzów Wlkp & & & & & & 3 & 3 & & & & \\
\hline Szczecin & & & & 5 & $\sim 10$ & & & & & & $x$ \\
\hline Jarocin & & & & & & & & & & & $10 \#$ \\
\hline Gdańsk & & 2 & & & & & & & & & 4 \\
\hline Tczew & & & & & & & & & & 3 & 3 \\
\hline Kalisz & & & & & & & & & 3 & & \\
\hline Chojnice & & & & & & 1 & & & & & \\
\hline Zielona Góra & & & & & & & 2 & & & & \\
\hline
\end{tabular}

In New Plymouth, in 2010, the Govett Brewster Gallery, a city council entity, organised PD, taking over the car parks outside the gallery with the event listed on the Rebar website. The gallery worked with ten artists with the aim of taking the gallery to the street. The installations were participatory and interactive, or performance based. A local architecture firm ran a lounge area for conversation about public and green space. In 2012 the New Zealand Institute of Landscape Architects (NZILA) began its involvement with Park(ing) Day in New Zealand. The Park(ing) Day Auckland Branch Facebook page was created on 22 September 2012, to document the day and continues to have this role. Many of the installations were informal, without barriers to traffic and less designed than those that would come later. Unitec landscape architecture students were involved in a popular installation, which people began to interact with even before it was totally set up; passersby could add 'Post It'-like notes to a map to state their wishes for Auckland in 2050 in response to the update to the Auckland City Centre Masterplan. A landscape architect who was involved as a student in 2012 and has been involved in PD ever since, considers that when he first participated there was not an appetite on the part of council to support the event. The PD participants were required to complete a traffic management plan and fill out a number of forms, which they did not do due an awareness that a lot of the thinking around PD was 'guerrilla tactical urbanism'. Instead, they paid the parking fee and fixed the ticket to the seat so as to satisfy the parking wardens.

Table 3. City council involvement (black—city council financial support; dark grey-cc agreement/ permission; light grey-independent-no support) and the amount of parking spaces taken over during PD (numbers). Additional key: +—number equal or larger; —estimated number; c-event cancelled due to bad weather; in — event partially indoors due to bad weather; ${ }^{*}$ - event moved to March; s-several locations including suburbs.

\begin{tabular}{|c|c|c|c|c|c|c|c|c|c|c|c|c|}
\hline & 2009 & 2010 & 2011 & 2012 & 2013 & 2014 & 2015 & 2016 & 2017 & 2018 & 2019 & 2020 \\
\hline Wellington & $1+$ & & & 25 & C & & $22 *$ & $17^{*}$ & 19 * & $25 *$ & $\begin{array}{l}\sim 25 \\
* \text { in }\end{array}$ & 22 * \\
\hline Auckland & $5+$ & & & $10+$ & $6+$ & $6+$ & $8+$ & $8+$ & $8+$ & $50 \mathrm{~s}$ & $40 \mathrm{~s}$ & \\
\hline Christchurch & 1 & & & & & $1+$ & 18 & 5 & & & & \\
\hline Queenstown & & & & 1 & & & & & & & & \\
\hline Dunedin & & & & & & & & & & & $1+$ & \\
\hline Hamilton & & & & & & & & & & $1+$ & 1 & \\
\hline $\begin{array}{c}\text { Tauranga and Mt. } \\
\text { Maunganui }\end{array}$ & & & & & & & & & & & 3 & \\
\hline New Plymouth & & 10 & & & & & & & & & & \\
\hline
\end{tabular}


In Auckland, in 2013, the installations were more designed than in previous years and included barriers to traffic. The public was still invited to pay the parking fee. In 2013 the Wellington Sculpture Trust, in association with the Wellington City Council (WCC), organised a Wellington version of Park(ing) Day which was cancelled due to bad weather. The council became involved as the trust sought permission for the occupation of parking spaces, and they were closely involved with design selection. The involvement was cross council as WCC City Arts and Events, the Parking Services Team and the Street Activities team collaborated. As time has gone on the council has been less involved as they have become familiar with PD.

From 2015, there was Park(ing) Day held every year in both Auckland and Wellington. In the year 2015, we saw the first Park(ing) Day organized and run by the Wellington Sculpture Trust in association with Wellington City Council. It was held in March, as were all subsequent Park(ing) Days, due to the bad weather experienced on the 2013 PD. One of the reasons it is held in March is to tie in with cruise ship visits. In 2015, there were 18 groups inhabiting 22 carparks. In Auckland, the same year there was also support from the council who saw it as a way to trial parklets quickly and inexpensively.

In 2016, a reduced version of Park(ing) Day spread to Christchurch. Gap Filler's Park(ing) Day project involved University of Canterbury students and ran for four hours. Gap Filler came about after the Christchurch earthquakes in 2010 and 2011—their website defines them as a placemaking and urban regeneration social enterprise [47].

Every year has seen changes to Park(ing) Day. From 2017, all installations in Wellington were located in a single street, Cuba Street, which has a lot of foot traffic, with the close proximity of the installations concentrating the atmosphere and enabling interaction between the participants. In 2018 the New Zealand Institute of Architects (NZIA) Festival of Architecture included the first Park(ing) Day installation in Manakau City (Māngere) and installations in Hamilton, as well as a sizable number of installations in Devonport and Auckland CBD.

In 2019, we saw Park(ing) Day celebrated in Tauranga and adjacent Mt. Maunganui, as well as in Dunedin for the first time. One installation in Tauranga used VR (virtual reality) technology to help people experience the city without cars. In Wellington, torrential rain forced most installations to indoor locations and as a result in 2020 there was a back-up day the following Friday (Figure 4).

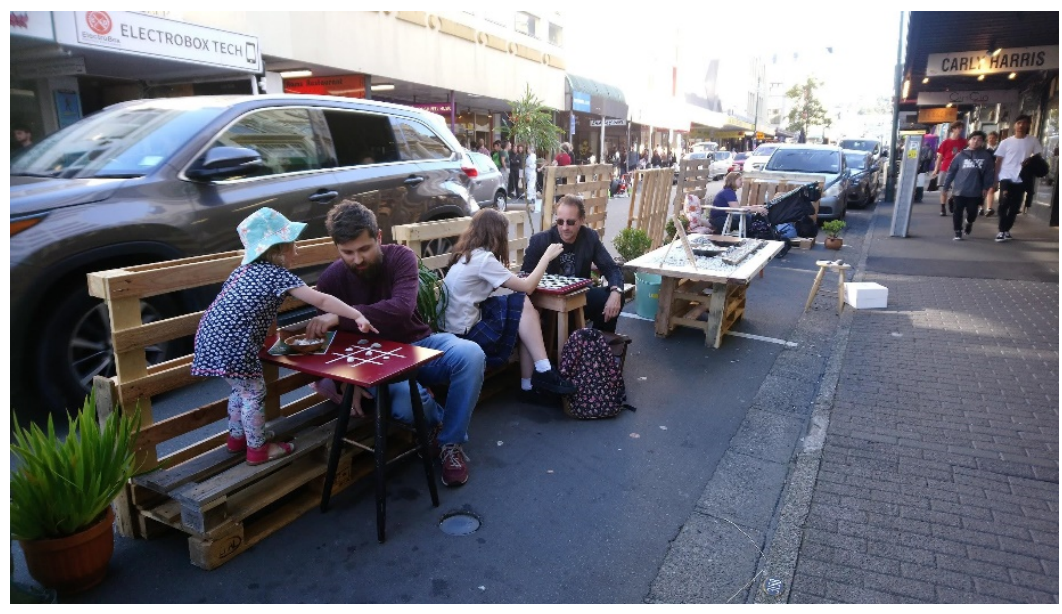

Figure 4. Park(ing) Day in Wellington (2020)—installation designed by K. Herman, M. Rodgers, J. Coppard, A. Meredith-Vaughan. (Photo M. Rodgers).

Wellington City Council continues to support PD for a number of reasons: it is a chance to have creativity in a public space; it has the potential to reach an audience who may not set foot in a gallery; it can encourage thinking about how we use our streets, make them pedestrian friendly and activate city spaces; it helps make the city a vibrant and dynamic space to be; and the value of cross council projects. The Wellington Sculpture Trust continues their involvement as they see this event as a valuable complement to the Trust's usual focus on the installation of permanent creative work 
to enhance the city's urban living spaces. A survey was undertaken of the photos in the Wellington Sculpture Trust archive of Park(ing) Day from 2015 to 2020 to determine if there had been a change in emphasis or theme over time (Table 4). The most striking finding was the change from the dominance in $2015 \mathrm{of}$ art/craft installations over installations that encouraged novel participation from the public, to an even, or almost even, split between the two from 2017 onwards. The other observation was that PD occupations featuring performance, the third most numerous category in 2015, gradually reduced to nil in 2020. Installations that sought to raise awareness of an issue were the third highest category overall, peaking in 2018 and reducing down again in 2020. The least numerous category contained those installations inspired directly by the first Park(ing) Day, that is, 'grass' + seat + plants, which only appeared in 2015 and 2016.

Table 4. Survey of Wellington Sculpture Trust Photo Archive of Park(ing) Day installation from years 2015-2020 showing repeating themes (not all PD installations were represented in archival photographs).

\begin{tabular}{ccccccc}
\hline & $\begin{array}{c}\text { Inspired Directly by } \\
\text { the First PD (Lawn + } \\
\text { Seat + Plants) }\end{array}$ & $\begin{array}{c}\text { Publicity } \\
\text { for a Cause }\end{array}$ & $\begin{array}{c}\text { Art/Craft Created } \\
\text { or Being Created }\end{array}$ & $\begin{array}{c}\text { Encouraging } \\
\text { Participation } \\
\text { by Public }\end{array}$ & Performance & $\begin{array}{c}\text { Recreation } \\
\text { of Nature }\end{array}$ \\
\hline 2015 & 1 & 1 & 6 & 2 & 4 & 1 \\
2016 & 1 & 1 & 7 & 5 & 2 & \\
2017 & & 1 & 7 & 7 & 2 & 2 \\
2018 & & 4 & 5 & 6 & 3 & \\
2019 & 2 & 4 & 5 & 2 & \\
2020 & & 1 & 9 & 7 & & \\
\hline
\end{tabular}

Parklets have only recently been a part of the urban fabric in New Zealand. The first in the country may have been the parklet outside the Tasting Room, a public bar in Courtenay Place, Wellington, which occupies three parking spaces and was set up in 2015. Since then it has not just been the larger centres that have adopted parklets. Palmerston North City Council has issued 'Parklet and Flex Space', a manual with design guidelines and specifications and there was a trial parklet in Masterton in 2019.

\section{Discussion}

\subsection{The Institutionalisation of Park(ing) Day and the Criticism of Parklets}

Park(ing) Day allows us to reimagine streets and public spaces with small, temporary examples of creative, green and fun 'acupuncture'. Its roots are 'tactical', community-led and unsanctioned [48]. The first edition of PD brought potentially subversive and critical commentary to the prevailing, conservative standards of urban planning. However, as an ephemeral and low-scale event PD has been viewed less radical than other similar movements, such as Critical Mass, which has sparked a noteworthy amount of conflicts between cyclists and motorists around the world [49]. PD did not steamroll public opinion and was a non-invasive, and rather nuanced tactical intervention [50]. The extensive media coverage of PD and the allure of the image of the transitory, reinvented, greenified parking space left people wanting more.

As such, tactical urbanism, and Park(ing) Day, represent a threat to the current order-a threat characterised by pot plants, street furniture, bikes, pedestrians, art, books, music, and chats-but a threat nonetheless! The best way to neutralise that threat, and undermine any subversive potential, is to co-opt the strategies being used by activists. Stripped of radical possibilities, divorced from grassroots, activist origins and instead imposed and managed by the government, tactical urbanism interventions become a way for cities to brand themselves as 'creative cities' (frankly, they're trying to look cool) while co-opting, commodifying and neutralising what are supposed to be alternative, creative imaginaries of the city [48].

PD has in many ways been taken over by institutions and municipalities. Often it has become another public relations stunt, an event that in a very safe, sanctioned scale and limited space showcased 
a pro-pedestrian and pro-cyclist approach. On the other hand, one can argue that what municipalities did by supporting PD around the world is 'innovation spotting' through which 'climate for change' could be created. The ideas proposed by the original Park(ing) Day have now been fully acknowledged as the way cities are heading by city designers. "Ludo Campbell-Reid, general manager of the council's Auckland Design Office, says Auckland Council is well aware of the problems arising from an ever-growing city and the importance of public spaces" [51]. As public transport and facilities like bike lanes improve, Campbell-Reid says more and more Aucklanders are calling for a less car-oriented city with a real change in the way people move around their city, from cars to public transport, cycling and walking [51].

PD is seen as one of the most successful tactical urbanism actions worldwide [50] mainly because of its (indirect) continuation through the parklet program. Parklets as a more permanent 'manifestation' of PD did not end the PD movement as such. PD developed into an institutionalised but more diverse and art-focused event. In many cases PD has also become more focused on the local community's needs, interests, and values. For example, an array of activities took place in a transformed parking space in San Francisco between 2006 and 2012 including urban farms, art installations, bike repairs, health clinics and the holding of same-sex wedding ceremonies [52].

Regarding parklets, as reports carried out within the San Francisco Great Streets project [32,53] only covered a few early parklets and produced conflicting results, it is difficult to establish the benefits for local businesses. "A goal of the whole project is to support local businesses, but in the first study, equally many adjacent businesses wanted to make the first formal parklets permanent as wanted to remove them" [32]. In the second study, only one of the businesses indicated an increase in their profits [53]. Littke [16] discusses the negative aspects of San Francisco's parklets including: the financial and time costs for the sponsor; the presence of feelings of not-in-my-back-yard; negative competition between businesses; and the maintenance and management needed by the city. Littke also considers that, even though parklets are part of a tactical urbanism movement, their institutionalized management risks losing creativity and alternative urban practices [16], qualities integral to the original Park(ing) Day and its early iterations. Additionally, "The park features and the green of the parklets also connect to a quick fix approach for sustainable green cities combating climate change" [16]. Parklets are viewed negatively by some as a form of greenwashing that, due to their low ecological functionality, make very little difference to climate mitigation with the benefits being decorative and symbolic [16].

"Despite the fact that parks and other public spaces have clear health and social benefits for citizens and financial value to cities, many still struggle to provide adequate levels of open space for their residents, especially in low-income neighborhoods" [23]. The first Park(ing) Day sought to create public open space in an area of the city underserved by public space [54]. This example has not been followed by the parklet program, with low income neighbourhoods still less likely to have open space or parklets as most parklets are in already popular and successful neighbourhoods [16]. In addition, most parklets are sponsored by cafes and restaurants; "If the goal is to foster neighbourhoods and communities, cities should target community groups, schools and public functions, and develop funding systems embedded in local activities and education. Cities should fully utilize the best aspects of the parklets—not succumb to the temptation to only use them as quick fixes and business enticements" [16].

\subsection{Tactical Urbanism and the Extension of Pedestrian Spaces During COVID19 Pandemic}

The 2020 edition of Wellington Park(ing) Day was organised on Friday 6 March just a week after the first reported COVID-19 case in New Zealand and by that day 4 cases had been reported. On 11 March, the WHO declared an official pandemic. New Zealand's first 'Level 3' pre-lockdown restrictions were put into effect on 23 March [55].

New rules and routines of social distancing became the 'new normal' around the world and walking and biking became highly recommended as safe methods of mobility in urban environments. "Whenever feasible, consider riding bicycles or walking" stated the World Health Organisation (WHO) on 21 April in the information sheet 'Moving around during the COVID-19 Outbreak' [56]. 
As of the 1 May 2020, more than 140 cities around the world implemented local actions to support walking and cycling during times of social distancing [57], with many of them incorporating parking spaces and street lanes. A tactical urbanism action of pop-up bike lanes and sidewalk widening in Auckland, New Zealand, is considered to be the first of this type of 'pandemic urbanism' response [58]. In Wellington, local landscape architecture firms see the possibility for the city to be a laboratory to "prototype and explore what city spaces designed for people would look like" [59].

Tactical urbanism in the time of social distancing became a part of urban policy and the governments that previously tested this approach now believe "the time is ripe to roll out the technique on an emergency-funded basis" [58]. Transport Minister, Julie Anne Genter, has invited cities in New Zealand to apply for $90 \%$ funding to widen sidewalks and carve out temporary cycleways, measures that can be put in place in hours and days rather than the weeks, months and years that it can often take to install such infrastructure [58]. These actions are taking place through the 'Innovating Streets for People Pilot Fund' [60] that supports pop-up, interim treatments that make it safer and easier for people walking and cycling in the city [61]. "Footpath extensions would use basic materials like planter boxes and colourful paint to carve out a bit more space in the street for people walking", said Julie Anne Genter [61].

Wellington Park(ing) Day 2020 on the central, iconic Cuba Street served as a temporary extension of the pedestrianised section of the street. Supported by the City Council Wellington PD could be seen as a pilot (prototype) for permanent changes to Cuba Street that would be in-line with recent municipal street and laneway upgrade projects [62,63].

During 'Level 2' COVID-19 restrictions that limited some business activities and prescribed social distancing, a new initiative similar to PD sprung up in Wellington. 'Picnics in Parks' is a grassroots activism movement focused on confronting the current use of parking spaces and bringing attention to how we can utilise space in our cities better year round as well as providing support to local businesses. The first Picnic in Park occurred on a street parking spot outside a barber shop, giving the option of an outdoors haircut.

Meanwhile, Warsaw City Road Authority has sped up works on removing parking spaces from pavements by moving them onto the road. About ten streets in the extended central area became a part of this plan in April 2020 [64]. This leads to permanent widening of pavements, often doubling the width of pedestrian space, and allows for social distancing. These changes are seen as long awaited in a city that in recent years was rather reluctant to make changes that reduced the number of car lanes and 'traffic capacity'.

\subsection{Park(ing) Day: Towards an Educational Tool for Architects and Landscape Architects}

PD has been used in various settings and contexts as an opportunity to educate both the general-public as well as those practicing urban design and policymaking. Students in all levels of education (secondary school to PhD studies) have been involved in the organisation and set up of PD events. Several 'parks' were built by pupils in both Auckland and Wellington. As part of the 2020 Wellington edition, Onslow College students built an outdoor classroom and Judah Jackson, a Wellington College student who won the People's Choice Award, created an installation that commented on accessibility and universal design ('put yourself in others' shoes'). The latter installation was prompted by the student helping his elderly grandmother and learning about accessibility issues. The teacher involved considers it hugely valuable for students to engage with the public as they are required to speak coherently and confidently to a wide range of people. At Onslow College, which has participated for four years, it is now a 'school calendar event' that everyone looks forward to. The school recognises the value of students engaging with the public, as well as thinking about real life scenarios with stakeholders, which have mainly been around the themes of sustainability and nature.

In 2014 the value of the ongoing collaboration in Auckland between NZILA professionals and Unitec students was highly praised: "Reflecting on this year's experience, there is no question that low cost installations driven by motivated individuals have the ability to generate a significant amount of 
interest and debate. We have learnt that tactical interventions provide us with valuable opportunities for social interaction and discussion on a personal level" [65].

During the third edition of PD in Christchurch (2016) three second year management students created installations as part of their course, which involved service learning and applying theory learnt in class to carry out a practical community based project. They also invited other students to create their own installations.

Community involvement as an integral part of teaching is consistent with alternative design studio methodologies that in Salama's [66] opinion are interchangeable: hands-on pedagogies of community design, design build and live project. All of them call for experimentation, a culture of relevant scholarship, innovation and discovery promoting independence in design decision-making, a sense of ownership and applicability to the 'real world'. In urban campuses, a parking space is also a local space that can be reshaped and temporarily inhabited. This enables informal contact between the institution, students and the community and leads to increased contact with a range of people beyond the academy. "The impact of situating pedagogical projects in community contexts offers not only enhanced pedagogical experiences, but also allows the work of students to be valued by people outside higher education" [67].

The design-build teaching method at its most pragmatic is understood as necessary for future professionals with exposure to hands-on building, materials, and site. Design-build "demystifies the construction site" while helping students to imagine and understand design, taking architecture from a drawing to a building [68].

PD differs from typical design-build teaching where outcomes of the students' work are delivered to local, regional or international communities in the form of developing or developed projects [69]. PD instead allows students to deliver and build a temporary solution, a 1:1 scale prototype.

Students can demonstrate and discuss possible changes to the public space 'on the spot' and experience how to persevere through unexpected situations and encounters.

Early PD events in Warsaw became social events for landscape architecture students and an informal, extracurricular extension of 'Art of Garden and Landscape Art' workshops that were established at the Warsaw University of Life Sciences a few years prior to the first Warsaw PD. In this class students were tasked to build temporary gardens, operating with low implementation budgets, re-using elements of previous projects, and recycling materials [70]. This resulted in ephemeral installations that were a balance between the practice of gardening, low-budget design [71,72] and the language of landscape art. As they moved away from their primary tactical urbanism roots, PD events have been more susceptible to artistic and performative approaches, positioning PD closer to the practices of landscape art. As with PD, landscape art installations can be a prototype, a chance to rethink public space that is unburdened by the size, regulation and function constraints of the normal practice of urban design. Landscape art and PD installations are both a form of architectural experiment that can more freely express innovative tensions and purposes. "They are opportunities to explore limits of using unusual materials and technologies, to verify viability of images, real or suggested in allegory, often provoking the audience response" [73].

$\mathrm{PD}$ as a recognised, established event presents an attractive structure, method or technique that can be incorporated in courses at several levels of education and has particular value for landscape architecture and architecture students. PD events enable them to be hands on, see the impact of their design, discuss topical issues with the public, design and work as a team, and explore upcycling and low budget, environmentally friendly design.

PD events have great potential as an area to apply a 'live projects' method offering "sites of creative, social and cultural exchange and transformative experiences and outcomes that allow students and staff to directly challenge or subvert the sometimes overpowering hidden curriculum of the apprenticeship-derived model of architectural education" [67]. 


\section{Conclusions}

PD is seen as one of the most successful tactical urbanism actions worldwide. It grew quickly and resulted in local urban improvements as well as having an impact on cityscapes globally, inspiring changes in policies and public space around the world. Parklet programs, often seen as a direct result of $\mathrm{PD}$, have not seen the demise of the PD movement but have contributed to its evolution. Case studies of the development of PD in geographically and culturally distant Poland and New Zealand (analysis of 76 events in 23 cities) present a similar narrative of successive popularisation and institutionalisation, as well as diversification (Figure 5).

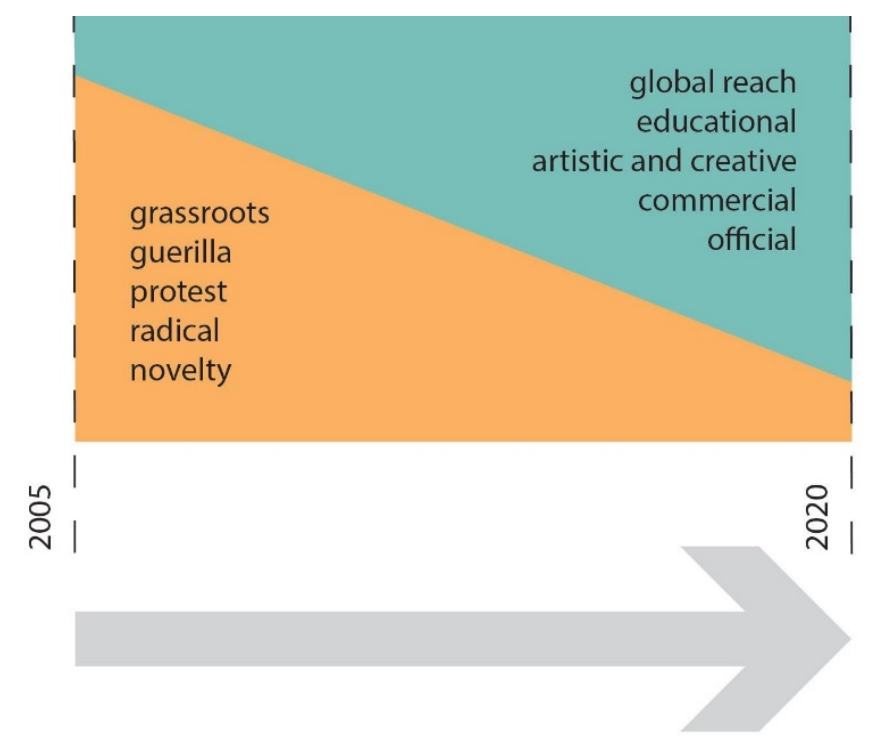

Figure 5. General trajectory of PD evolution to the present day.

The typical progress of institutionalisation included two to four stages where PD was: independently organised by activist groups (1), officially permitted by city councils (2), financed by city councils (3) and organised by city officials (4). In the analysed cases, once the organisation of the event is taken over by the city council or financed by the city it never goes back to the scale and grassroots character of the original guerilla, activist action. Municipalities and city councils have come to look at grassroots actions such as PD for inspiration and also to entice social involvement, activity and progress their political agenda (represented by urban development strategies).

The globalisation of PD resulted in heterogeneity of local character and presents a variety of approaches and goals. In Poland, where PD was strongly connected to European Mobility Week and Car-Free Day, when city councils got involved it became a form of sanctioned 'publicity' for pedestrian and bike friendly cities. In many cases PD seamlessly evolved into an official EMW/CD picnic on parking lots and the guerilla or protest character receded.

In New Zealand, art institutions and design offices have evolved PD into a large event that engages artists, architects, landscape architects and professionals as well as school children.

In some cases, PD can now be seen as a well-recognised product with potential commercial value. Architectural offices see it as an opportunity to have a public presence, to advertise and promote their business, and to engage with local communities. It encourages both professionals and students to engage in playful experimentation providing a venue to develop innovative designs, explore new forms and materials (often reused) and improve teamwork skills.

PD can be a tool for the education of the designers of the future. As an established, recognised action and an 'attractive' idea PD has great educational potential as a venue for implementing methods such as design-build and live projects. PD is also valuable as a way of introducing to the general public prototypes and ideas for potential changes to the structure of urban fabric, such as moving 
from car dominated cityscapes towards greater equality of space appropriation and appreciation of the social role of the pedestrianised public streetscapes. Tactical urbanism and low-budget approaches have solidified their position as urban planning strategies, becoming even more relevant during the COVID-19 pandemic with multiple accelerated reactions and pop-up changes in public spaces around the globe.

Author Contributions: Conceptualization, methodology and conclusions-K.H.; case studies, analyses, interviews and writing - equal contributions from K.H. and M.R.; language editing-M.R. All authors have read and agreed to the published version of the manuscript.

Funding: This research project was possible thanks to the Internal program of WULS-SGGW financing international mobility of young academic staff and Ph.D. students.

Acknowledgments: Authors would like to thank the Wellington Sculpture Trust for providing access to Park(ing) Day archives.

Conflicts of Interest: The authors declare no conflict of interest.

\section{References}

1. Great Britain Ministry of Transport. Traffic in Towns: A Study of the Long Term Problems of Traffic Urban. Areas; Reports of the Steering Group and Working Group Appointed by the Minister of Transport; H.M. Stationery Office: London, UK, 1963.

2. SCAFT Group. The SCAFT Guidelines 1968: Principles for Urban Planning with Respect to Road Safety; Statens Planverk and Statens Vägverk: Stockholm, Sweden, 1968.

3. Jacobs, J. The Death and Life of Great American Cities; Vintage: New York, NY, USA, 1992.

4. Qu, L.; Hasselaar, E. Making Room for People: Choice, Voice and Liveability in Residential Places; Techne Press: Amsterdam, The Netherlands, 2011.

5. Verwer, D. Planning residential environments according to their real use by children and adults. Ekistics 1980, 47, 109-113.

6. Hellema, D.; Wiebes, C.; Witte, T. Domestic measures. In The Netherlands and the Oil Crisis: Business as Usual; Amsterdam University Press: Amsterdam, The Netherlands, 2004; pp. 97-116. ISBN 9789053564851.

7. Kingsley, P. How to Be Danish: A Journey to the Cultural Heart of Denmark; Short Books: London, UK, 2012; ISBN 9781780721347.

8. Carless Days Introduced|NZHistory, New Zealand History Online. Available online: https://nzhistory.govt. nz/carless-days-introduced (accessed on 23 April 2020).

9. Britton, E. Thursday: A Breakthrough Strategy for Reducing Car Dependence in Cities. Available online: https:/web.archive.org/web/20120204173622/http://www.ecoplan.org/carfreeday/general/thursday. htm (accessed on 23 April 2020).

10. Carlsson, C. Critical Mass: Bicycling's Defiant Celebration; AK Press: Chico, CA, USA, 2002.

11. Blickstein, S.; Hanson, S. Critical mass: Forging a politics of sustainable mobility in the information age. Transportation 2001, 28, 347-362. [CrossRef]

12. Melia, S. On the road to sustainability: Transport and car-free living in Freiburg. In Report for WHO Healthy Cities Collaborating Centre; 2006. Available online: www.carfree.org.uk/038 (accessed on 23 April 2020).

13. Wikipedia Contributors List of Car-Free Places. Available online: https://en.wikipedia.org/w/index.php? title=List_of_car-free_places\&oldid $=957350699$ (accessed on 16 June 2020).

14. Crawford, J.H. Carfree Cities; International Books: Dublin, UK; Discover Books: Toledo, OH, USA, 2000; ISBN 9789057270376.

15. Nieuwenhuijsen, M.J.; Khreis, H. Car free cities: Pathway to healthy urban living. Environ. Int. 2016, 94, 251-262. [CrossRef] [PubMed]

16. Littke, H. Revisiting the San Francisco parklets problematizing publicness, parks, and transferability. Urban For. Urban Green. 2016, 15, 165-173. [CrossRef]

17. Ferreri, M. The seductions of temporary urbanism. Ephemera 2015, 15, 181-191.

18. Merker, B. Taking place: Rebar's absurd tactics in generous urbanism. In Insurgent Public Space. Guerrilla Urbanism and the Remaking of Contemporary Cities; Hou, J., Ed.; Roudedge: New York, NY, USA, 2010; pp. 45-58. ISBN 9780203093009. 
19. Coombs, G. Park(ing) day. Contexts 2012, 11, 64-65. [CrossRef]

20. Chen, X.; Orum, A.M.; Paulsen, K.E. Introduction to Cities: How Place and Space Shape Human Experience; John Wiley \& Sons: Hoboken, NJ, USA, 2018; ISBN 9781119167716.

21. Endres, D.; Senda-Cook, S.; Cozen, B. Not just a place to park your car: Park(ing) as spatial argument. Argum. Advocacy 2014, 50, 121-140. [CrossRef]

22. Chase, J.; Crawford, M.; Kaliski, J. Everyday Urbanism; Monacelli Press: New York, NY, USA, 2008; ISBN 9781580932011.

23. Mike, L.; Anthony, G. Tactical Urbanism: Short-Term Action for Long-Term Change; Island Press: Washington, DC, USA, 2015.

24. Houghton, K.; Foth, M.; Miller, E. Urban acupuncture: Hybrid social and technological practices for hyperlocal placemaking. J. Urban Technol. 2015, 22, 3-19. [CrossRef]

25. Hou, J. Insurgent Public Space: Guerrilla Urbanism and the Remaking of Contemporary Cities; Routledge: New York, NY, USA, 2010; ISBN 9781136988028.

26. Finn, D. DIY urbanism: Implications for cities. J. Urban. Int. Res. Placemaking Urban Sustain. 2014, 7, 381-398. [CrossRef]

27. Prawata, A. Creative User Generated Urbanism. Procedia Soc. Behav. Sci. 2015, 184, 232-239. [CrossRef]

28. Pascaris, J.P. Healing Neighbourhoods through Urban Acupuncture. Master's Thesis, Ryerson University, Toronto, ON, Canada, 2012.

29. Rebar Group. The Park(ing) Day Manifesto: User-Generated Urbanism and Temporary Tactics for Improving the Public Realm; Self-published (Rebar Group): San Francisco, CA, USA, 2011.

30. Loukaitou-Sideris, A.; Brozen, M.; Callahan, C.K.; Brookover, I.; LaMontagne, N.; Snehansh, V. Reclaiming the Right-of-Way: A Toolkit for Creating and Implementing Parklets; UCLA Complete Streets Initiative, Luskin School of Public Affairs: Los Angeles, CA, USA, 2012.

31. Birdsall, M. Parklets: Providing space for people to park... themselves. Inst. Transp. Eng. ITE J. 2013, 83, 36.

32. Pratt, L. Divisadero Trial Parklet Impact Report (PDF); San Francisco Great Streets Project: San Francisco, CA, USA, 2010.

33. Lavine, E. Spectacle in the new green city. Berkeley Plan. J. 2012, 25, 140-149. [CrossRef]

34. Gould, S. Parklets: Tiny Parks with Big Impacts for City Streets; SvR Design: Seattle, WA, USA, 2012.

35. Dai, D. From Parking to Park: Transportation Impacts and Value of Parklets; Congress for the New Urbanism: Chicago, IL, USA, 2013.

36. Groundplay-When Imagination Goes Public. Available online: https://groundplaysf.org/ (accessed on 22 April 2020).

37. Francis, M. A case study method for landscape architecture. Landsc. J. 2001, 20, 15-29. [CrossRef]

38. Dandekar, H.C. Some uses and potentials of qualitative methods in planning. J. Plan. Educ. Res. 1986, 6, 42-49. [CrossRef]

39. Johnston, M.P. Secondary data analysis: A method of which the time has come. Qual. Quant. Methods Libr. 2014, 3, 619-626.

40. Devisch, O.; Hannes, E.; Trinh, T.A.; Leus, M.; Berben, J.; Hiến, Đ.T. Research-by-design framework for integrating education and research in an intercultural parallel design studio. Front. Archit. Res. 2019, 8, 406-414. [CrossRef]

41. Megahed, Y. On research by design. ARQ Archit. Res. Q. 2017, 21, 338-343. [CrossRef]

42. Hauberg, J. Research by Design-A research strategy. AE Rev. Lusófona Archit. Educ. 2011, 5, 46-56.

43. Monteith, W. Participant Observation in Urban Arenas: Uncovering Hidden Rules in a Ugandan Marketplace; SAGE Publications, Ltd.: Thousand Oaks, CA, USA, 2014. [CrossRef]

44. Yin, R.K. Participant-Observation and the Development of Urban Neighborhood Policy; RAND Corporation: Santa Monica, CA, USA, 1972.

45. Roggema, R. Research by design: Proposition for a methodological approach. Urban Sci. 2016, 1, 2. [CrossRef]

46. Matthew Passmore, R. PARK(ing) Day 2009. Available online: https://www.parking-net.com/parking-news/ park-ing-day-2009 (accessed on 29 April 2020).

47. Gap Filler|Gap Filler Is a Creative Urban Regeneration Initiative in Christchurch, New Zealand. Available online: https://gapfiller.org.nz/ (accessed on 16 May 2020).

48. Osborne, N. Right to the City-Brisbane The Problem with Park(ing) Day. Available online: https://www. researchgate.net/publication/309666084_The_Problem_with_Parking_Day (accessed on 16 June 2020). 
49. Wikipedia Contributors Conflicts Involving Critical Mass. Available online: https://en.wikipedia.org/w/ index.php?title=Conflicts_involving_Critical_Mass\&oldid=926102450 (accessed on 5 May 2020).

50. Davidson, M.M. Tactical Urbanism, Public Policy Reform, and "Innovation Spotting" by Government: From Park(ing) Day to San Francisco's Parklet Program; Massachusetts Institute of Technology: Boston, MA, USA, 2013.

51. PARK[ing] Day Highlights Importance of Urban Public Spaces|Newshub. Available online: https://www.newshub.co.nz/home/new-zealand/2019/09/park-ing-day-highlights-importance-of-urbanpublic-spaces.html (accessed on 5 May 2020).

52. Olberding, J. Social Enterprise and Special Events; Taylor \& Francis: Abingdon, UK, 2016; ISBN 9781317375494.

53. Pratt, L. Parklet Impact Study; San Francisco Great Streets Project; City and County of San Francisco: San Francisco, CA, USA, 2011.

54. Bela, J. User-generated urbanism and the right to the city. In Now Urbanism: The Future of City is Here; Routledge: New York, NY, USA, 2015; pp. 149-164.

55. COVID-19-Current Cases. Available online: https://www.health.govt.nz/our-work/diseases-andconditions/covid-19-novel-coronavirus/covid-19-current-situation/covid-19-current-cases (accessed on 5 May 2020).

56. Moving around during the COVID-19 Outbreak. Available online: http://www.euro.who.int/en/health-topics/ health-emergencies/coronavirus-covid-19/novel-coronavirus-2019-ncov-technical-guidance/coronavirusdisease-covid-19-outbreak-technical-guidance-europe/moving-around-during-the-covid-19-outbreak (accessed on 1 May 2020).

57. Combs, T. Local Actions to Support Walking and Cycling During Social Distancing Dataset. Available online: http://pedbikeinfo.org/resources/resources_details.cfm?id=5209 (accessed on 5 May 2020).

58. Reid, C. New Zealand First Country to Fund Pop-Up Bike Lanes, Widened Sidewalks During Lockdown. Forbes Magazine. Available online: https://www.forbes.com/sites/carltonreid/2020/04/13/new-zealand-firstcountry-to-fund-pop-up-bike-lanes-widened-sidewalks-during-lockdown/ (accessed on 5 May 2020).

59. Crisis Creates Opportunity-Isthmus. Available online: http://isthmus.co.nz/thinking/crisis-createsopportunity/ (accessed on 5 May 2020).

60. NZ Transport Agency Innovating Streets-All updates|Waka Kotahi NZ Transport Agency. Available online: https://www.nzta.govt.nz/roads-and-rail/innovating-streets/ (accessed on 4 May 2020).

61. Govt to Fund Temporary Cycleways and Footpaths Post COVID-19 Lockdown. Available online: https://www.beehive.govt.nz/release/govt-fund-temporary-cycleways-and-footpaths-post-covid19-lockdown (accessed on 4 May 2020).

62. Central City Framework. Available online: https://wellington.govt.nz/your-council/plans-policies-andbylaws/policies/central-city-framework (accessed on 4 May 2020).

63. Eva + Leeds Street Upgrage|NZ Institute of Landscape Architects. Available online: https://nzila.co.nz/ showcase/eva-leeds-street-upgrage (accessed on 4 May 2020).

64. Bezpieczne chodniki. Przenosimy Parkowanie na Jezdnię-Zarząd Dróg Miejskich w Warszawie. Available online: https://zdm.waw.pl/aktualnosci/bezpieczne-chodniki-przenosimy-parkowanie-na-jezdnie/ (accessed on 1 May 2020).

65. Wilson, L. Park(ing) Day. Available online: http://www.chowhill.co.nz/chowhill-blog/park-ing-day (accessed on 14 May 2020).

66. Salama, A.M. Spatial Design Education: New Directions for Pedagogy in Architecture and Beyond; Routledge: New York, NY, USA, 2016; ISBN 9781317051527.

67. Morrow, R.; Brown, J.B. Live projects as critical pedagogies. In Live Projects: Designing with People; RMIT University Press: Melbourne, Australia, 2012.

68. Canizaro, V.B. Design-build in architectural education: Motivations, practices, challenges, successes and failures. ArchNet-IJAR Int. J. Archit. Res. 2012, 6, 20.

69. Folić, B.; Kosanović, S.; Glažar, T.; Fikfak, A. Design-build concept in architectural education. Archit. Urban Plan. 2016, 11, 49-55. [CrossRef]

70. Gawryszewska, B.; Herman, K.; Myszka-Stapór, I. Ogrody w Teorii i Praktyce Pracowni Sztuki Ogrodu $i$ Krajobrazu; Stowarzyszenie Genius Loci: Warszawa, Polska, 2018; ISBN 9788395295607.

71. Herman, K.; Sbarcea, M.; Panagopoulos, T. Creating green space sustainability through low-budget and upcycling strategies. Sustain. Sci. Pract. Policy 2018, 10, 1857. [CrossRef] 
72. Herman, K. Practices in low-budget landscape architecture. Ephemera 2015, 15, 279.

73. Ifengspace (Ed.) Landscape Installation Art; Basheer Graphic Books: Singapore, 2013; ISBN 9789810755676.

(C) 2020 by the authors. Licensee MDPI, Basel, Switzerland. This article is an open access article distributed under the terms and conditions of the Creative Commons Attribution (CC BY) license (http://creativecommons.org/licenses/by/4.0/). 